\title{
THE SOCIAL THOUGHT OF THE ACTION FRANÇAISE
}

The Action Française was the most notorious reactionary movement x twentieth-century France. ${ }^{1}$ From the Dreyfus Affair to the fall of he Vichy Regime it carried on its campaign against "the principles of 789", which many Frenchmen (and other Western Europeans) uistakenly blamed for the "evils" of modern industrial society. But it epresented neither the frustrated lower-middle classes that were ttracted to fascism, nor the genteel bien-pensants who pined for the good old days" under Louis XVI or Charles X. Its leaders were café itellectuals who flaunted their newly acquired devotion to the lonarchy and the church. They were professional nativists clamoring Ir a return to the traditional virtues of a golden age that never risted. Their utopia was a highly intellectualized daydream invented y. Charles Maurras.

rom a philosophical point of view Maurras was the Action Française. le served as its infallible prophet and pope, though many of his leas were themselves derivative. ${ }^{2}$ His "organizing empiricism"

The Action Française was founded in 1899 by Charles Maurras and Henri Vaugeois. carried on its activities without interruption until it was proscribed by the Liberation svernment in late 1944. During its heyday (1910-1926) it had thirty to forty thousand gistered members, and a number of prominent writers, academicians, prelates, and my and navy officers were sympathetic to it. It had lost the support of the Church in 126, and in 1937 the royalist pretender disavowed it. In the thirties it was also losing me of its younger zealots to the nationalist and fascist leagues. Nevertheless, the biting tire of Léon Daudet continued to attract readers to its daily newspaper, and Maurice ajo and his Camelots du Roi still drew crowds to their street demonstrations. Vaugeois ed in 1916, Daudet in 1942, Pujo in 1951 and Maurras in 1953.

The sources of Maurras's thought have been analyzed by William Curt Buthman, The ise of Integral Nationalism In France (New York: Columbia University Press, 1939); ratiotte Touzalin Muret, French Royalist Doctrines Since The Revolution (New York: slumbia University Press, 1933); Alphonse V. Roche, Les idées traditionalistes en ance de Rivarol à Charles Maurras (Urbana, Illinois: The University of Illinois Press, 137); and Michael Curtis, Three Against The Republic: Sorel, Barrès, and Maurras 'rinceton, New Yersey: Princeton University Press, 1959). 
stemmed partly from Comte and Sainte-Beuve, his "positivist" approach to history from 'Taine, his admiration for the Old Regime from De Bonald, his federalism and corporatism from Proudhon and La Tour Du Pin, his antisemitism from Drumont, and his nationalism from Barrès. Maurras did not take over the theories of any of these men completely. He drew upon them eclectically to support his own outlook, which was that of an aesthete and literary critic.

Maurras began his career as a literary critic in the late 1880 's and he once said that his political and social thought were the by-products of his aesthetic principles: ${ }^{1}$

"I battled for ten years for the traditions of French taste, but I entertained no hope of seeing them restored until the day when I conceived the possibility of re-establishing the ensemble of our national traditions."

Hence, Maurras the literary critic became Maurras the royalist in order to restore a society congenial to the classical tradition of French literature and faithful to the Greek principles of beauty handed down to France by Rome. He was an aesthete before he was a nationalist, and a nationalist before he became a royalist. His nationalism was cultural before it finally became political.

Maurras's social thought must be pieced together from his scores of books and thousands of articles written over a period of sixty-five years, for the method he used to construct it was dialectical. He resolved the apparent paradox of an apostle of authority championing the value of argument by restricting it to theoretical matters, while proscribing it from the field of action. ${ }^{2}$ Like a true doctrinaire, he separated ends from means and justified all sorts of opportunism regarding the latter. He was ready to achieve his goals "par tous les moyens", and he used the tactics of logic and politics - both of which he enjoyed aesthetically - in the service of a philosophical ideal.

The best way to present Maurras's ideas is to examine his basic assumptions and prejudices first and then describe his views on politics, society, economics, and the church. He himself admitted that it was not his philosophy but the fact that he had been born a Frenchman that made him see the monarchy as the "natural" regime for France. ${ }^{3}$ Unlike Montesquieu, he felt that all types of government

${ }^{1}$ Gazette de France, December 1 2, I 901 .

2 Mes idées politiques (Paris: Fayard, 1937), p. I3r.

${ }^{3}$ Enquête sur la Monarchie (Versailles: Bibliothèque des Oeuvres Politiques, 1929), p. 65. 
should be based on authority, order, and hierarchy. ${ }^{1}$ The keystone of his doctrine is not monarchism but a strong antidemocratic bias.

Since Maurras insisted that democracy brings equality with it, he spent his life attacking both of these values. Like Taine, he assumed that most modern men are little better than their primitive forbears. They may have developed further mentally, but only a few superior intellects escape mediocrity. ${ }^{2}$ The ideal of equality is bad, he argued, because it undermines societies and destroys civilizations. He equated civilization with quality and democracy with quantity and equality ${ }^{3}$ and said that one had to choose between inequality and death. ${ }^{4}$

To Maurras an egalitarian society meant "a government of numbers", 5 which was incapable of preserving the order that is essential to civilized communities, and which could only lead to decadence and anarchy. Because he assumed that hierarchy - or stratification - was natural to all types of human organization, Maurras wanted to revive what he called "protective and necessary inequalities"6 in the form of hereditary privileged classes. Privilege alone guarantees quality - by restraining man's envy and cupidity and by satisfying his desire for harmony, order, and status. ${ }^{7}$ Finally, according to Maurras, the whole system can work only if the principle of authority is recognized by all.

Why did these basic assumptions and prejudices lead Maurras to become a monarchist? He did not believe that monarchies exist by virtue of any special divine right. On the contrary, he maintained that all legitimate power is based on "beneficent force" and that those who hold it are justified by the results they achieve. ${ }^{8}$ Even so, a king cannot function effectively unless his office is hereditary: "The only rational and sensible form of the authority of one person is that which remains in a single family, from first born to first born, according to a law that excludes competition."9 Otherwise, a dictator or an elected monarch would do just as well. Maurras saw the elimination of competition for power as the main benefit of hereditary monarchy. By substituting heredity for election he hoped to overcome the "evils" of democracy. ${ }^{10}$

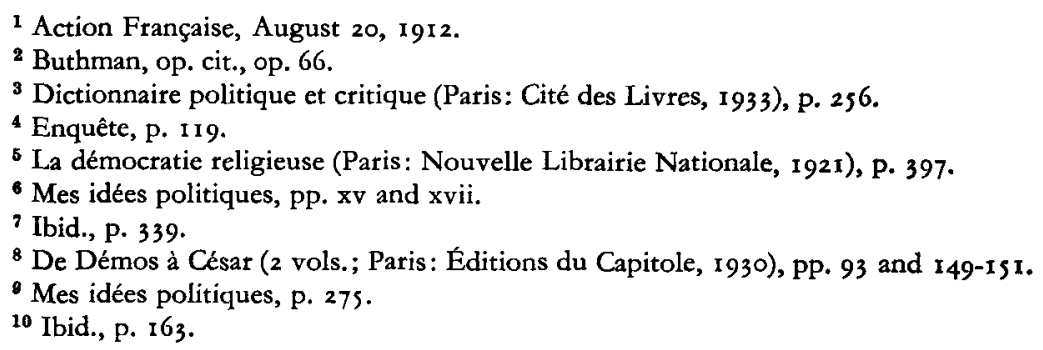


Maurras's political thought is dominated by a conceptual framework that is essentially social: "Monarchy is neither universal, nor eternal; what is eternal and universal is government by families." 1 Man's need to live in common is more "necessary" than the existence of the state or of a particular nationality. ${ }^{2}$ In his polemics Maurras often seemed to consider forms of government - especially the monarchy - as ends in themselves. But, like the Greek philosophers, he equated "politics" with the good society in his theoretical writings.

According to Maurras, the group is more important than the individual, and its smooth functioning must take precedence over the rights of man. The rulers in any society must have more privileges and inherited economic security than the ruled, ${ }^{3}$ though everyone should have a "place". There should also be as little social mobility as possible in order to avoid competition for status, which destroys respect for authority and weakens the established order. ${ }^{4}$ Maurras would allow a few talented commoners to rise, but he abhorred the modern mass striving to "get ahead", as well as the danger of some people becoming déclassés in a highly competitive economic environment.

It is an open question as to where and when Maurras saw his ideal society in the past. He could have found it in the Middle Ages, in seventeenth-century France or Spain, or even in the England of 1900. For, though Maurras disliked everything British, he thought that most Englishmen of that period knew their "place" and respected their "betters" to a greater extent than Frenchmen. He seemed to like the period before $17^{89}$ in his own country, but he was also attracted to earlier aristocratic or oligarchical republics - like Athens, Rome, Carthage, and Venice - where power was inherited. In fact, he mentioned several of these as examples of his dictum that "the government of families is the eternal good". ${ }^{5}$

Maurras said that the whole of France's history required her people to submit to the authority of the royal family. ${ }^{6}$ Only in this way could their country remain a nation - instead of becoming a mere geographical expression, as Gaul had been when the Romans arrived. For France cannot be ruled by a business elite, like Carthage, a landed gentry, like Rome, or a priestly caste, like India. France is too complex socially and economically for any kind of hereditary government except a monarchy. The republic is monstrous because it allows

1 La démocratie religieuse, p. II6.

2 Action Française, July 23, 1916.

3 Ibid., August 4, 1914 and April 4, 1916.

4 Revue Hebdomadaire, December 15, 1923.

5 La démocratie religieuse, p. 84.

6 Mes idées politiques, p. 266. 
groups with various interests to try to control it, thus leading to the disintegration of the national community. Only a king can resolve the conflicting concerns of its citizens. ${ }^{1}$

In the modern world, where all nations sought to further their own ends, and where there was no common political bond outside of the fatherland, Maurras believed that the nation state was the best guardian of a community's values. ${ }^{2}$ The Roman Empire had once united many fatherlands and provided two centuries of "peaceful coexistence". In the Middle Ages, the Catholic Church had also been a kind of supranational political organization, but all semblance of unity had disappeared after the Reformation. Since then the nations of Europe had become political rivals in an unrestrained struggle for power. ${ }^{3}$ Therefore, the people who loved France would have to give their first thoughts to her vital interests. The national integrity and safety were supposed to be looked after by the state. But what kind of government did the French state have? Was it able to fulfill this duty?

Having asked himself these questions Maurras concluded that the Third Republic was incapable of preserving the national interests and safety of France because it was based on the false principles of the Revolution. His passion for order in society made him anti-individualistic; his contempt for the common man made him antidemocratic; his nativism and narrow racism made the ideal of brotherhood repugnant to him. Consequently his whole point of view was antithetical to the slogans of the revolutionary tradition: Liberté, Égalité, Fraternité.

For Maurras religious individualism was embodied in the Reformation; political individualism was the guiding principle of the Revolution; and individualism in art was the essence of Romanticism ${ }^{4}$ (so that the Reformation, the Revolution, and the Romantic movement were all bad in his eyes). Individualism was a false ideal for society because it cleared the way for disorder and chaos. Maurras insisted that society did not arise from a contract of wills, but from a fact of nature, ${ }^{5}$ and he pointed to the Dreyfus Affair as a tragic illustration of the havoc that an appeal to the rights of the individual could wreak. If individualism were a true value, the Dreyfusards would have been justified in disorganizing the army, public opinion, and the defense of

\footnotetext{
1 Enquête, p. 346.

2 Ibid., p. 472.

3 Ibid., P. 4I 2.

4 Ibid., p. 67.

5 Ibid., p. 79 .
} 
the state itself, for the sake of one person. ${ }^{1}$ Maurras believed that they were obviously not justified in doing so.

The Revolution, according to Maurras, had diverted the function of the state from that of guardian of the public safety to that of guarantor of the falsely-called "natural rights" of the individual. As a result, all the social ties among Frenchmen were relaxed or dissolved, and France was reduced to a condition of atomization in which each person lived isolated from his individual competitors. Like the bulk of Maurras's analysis, this observation overlooks the economic causes of social change. Maurras criticized the revolutionary leaders for their laissez-faire economic policies, their destruction of the church's control over the family and education, and their abolition of class privilege. But he did not see that, in substituting contract for status as the basis of society, the middle classes were trying to use legal means - culminating in the Napoleonic Code - to impose a whole new value-system on the rest of the country. For they installed a rational economic order in which precapitalist occupational and administrative groups no longer had a meaningful function.

Maurras resented the efforts of the new regime to destroy these groups and all the secondary institutions that had made French society into a nation. The professional gilds were abolished, while charity, education, and even science - as a result of government control of the universities and the Institut de France - became state services. In addition, the provinces were obliterated, and the privileges of the towns and the communes were subordinated to the central authority. ${ }^{2}$ Maurras thought that even the family - the smallest social unit in human society - was being supplanted by the individual. Every natural bond except that of common nationality was corrupted by the false philosophy of individualism. And the Dreyfusards, according to Maurras, were willing to sacrifice the nation itself rather than submit to the condemnation of one man.

In order to restore France to her former greatness, the secondary institutions that the Revolution had destroyed had to be revived, and the monarchy put back in power. Sixty years ago Maurras said that there were several groups in France campaigning for the restoration of the family, the liberties of the communes, the provinces, and the professional corporations, as well as those that wanted to re-establish a stable principle of political authority. ${ }^{3}$ The monarchy, which was traditional, hereditary, antiparliamentary, and decentralizing, could

1 Ibid., p. 73.

2 Ibid., p. 83.

3 Gazette de France, May 6, I 899. 
satisfy all their demands. As a matter of fact, the monarch alone could do so. Maurras summarized his view that royalism was the only integral and complete nationalism as follows: ${ }^{1}$

"The king incarnates the conservative instinct of the nation. Thus, the king will govern. The assemblies - the real social representation of the nation - will control the government. The country will administer itself, thanks to the free exercise of the rights of association, from which decentralization is born."

As Maurras knew, the reactionaries were not the only nationalists in France at the turn of the century. There were others who wanted to see a dictator in the Elysée palace and the functions of parliament reduced to a minimum. The remnants of the Boulangist movement led by Déroulède and Barrès had been ready to reform the republic along nationalist lines without destroying it completely. Maurras himself insisted that a nationalist and conservative republic was impossible, not only because of the false principles on which it was based, but also because it was controlled by a bloc of non-French cosmopolites. He called this group the "four confederated states": Jews, Freemasons, Protestants, and resident aliens (métèques). ${ }^{2}$ They ran the French state for their own purposes and would never allow it to change. ${ }^{3}$

Maurras charged that this bloc, which he also referred to as the "Old Republican Party", was against everything that an ordered French society demanded. It opposed a strong army; it pillaged the wealth of the country in order to subsidize democracy; it was anti-Catholic; it fostered the principles of the Revolution. ${ }^{4}$ Obviously, the state must be wrested from the hands of the people in this bloc and given back to true French leaders. What Maurras refused to see was that, in the twentieth century, the "Old Republican Party" included not only Jews, Freemasons, Protestants, and méteques, but also the majority of the French bourgeoisie. There were many wealthy middle-class Frenchmen who might have wished for a more conservative government and more repressive measures against the increasing threat of socialism, but few of them had any enthusiasm for a return to the Old Regime.

In the crises of the interwar period - especially in 1926, 1934, and 1936 - wealthy conservatives who feared a Communist revolution turned to more modern types of extremist movements than the Action

1 Enquête, p. I7I.

2 La démocratie religieuse, p. 245.

${ }^{3}$ Enquête, p. 535 .

4 Ibid., pp. $535-536$. 
Française in order to prevent such a catastrophe. Maurras too was sensitive to the Communist danger. Nevertheless, he continued to insist that the hereditary monarchy alone could satisfy the interests of all Frenchmen, for the republic catered only to the plutocracy. Maurras maintained that this group already had too much power, as was inevitable in a democracy, where votes and men could be bought. ${ }^{1}$ He shared the Socialists' resentment of government by the rich, and he opposed socialism on political rather than economic grounds. The nationalist monarchy, once it had purged this ideology of its egalitarian and cosmopolitan aspects, could, according to him, pursue a socialist policy, ${ }^{2}$ in the sense of protecting the welfare of all classes and controlling economic competition.

Maurras championed the monarchy because, as a personal government, it would avoid the anonymity and anarchy of the existing regime and would prevent the state from falling into the hands of "Finance". 3 It is interesting that the prophet of counterrevolution should share the same feeling as Marx regarding the control of the bourgeois state by the wealthy capitalists. According to both thinkers this had come about as a result of nineteenth-century liberalism, with its emphasis on cut-throat competition. But Maurras was concerned with restoring a quasi-feudal society, not with creating a classless one based on an industrial economy. He said that democracy, in the name of abstract Liberty, suppressed individual liberties and ended in despotism. ${ }^{4}$ The Liberty principle uprooted the individual from his family, his province, and his occupation for the benefit of the state.

It was only in these traditional contexts, Maurras believed, that the individual person was free to express himself and to feel secure. For this reason, in addition to calling for the rehabilitation of the family and diverse professional organizations, Maurras sought to restore the old provinces as centers of community activity. He wanted to undo the work of the Revolution, which had destroyed these and replaced them with artificial departements, which he called "the worst antiphysical mechanisms applied to the body of France."5 The departement prevented traditional local life from expressing itself. Consequently, it must be abolished, and the country's administrative divisions must again be made to conform to geography and history. The monarchy,

1 Action Française, August I, I92 I.

${ }^{2}$ Gaulois, Germains, Latins (Paris: Nouvelle Librairie Nationale, 1926), p. 171.

3 Kiel et Tanger, p. 390.

4 La démocratic religieuse, p. 295.

5 La République et la décentralisation. Un débat de 1903 (Paris: Nouvelle Librairie Nationale, 1923), p. 87 . 
Maurras claimed, was traditionally sympathetic to the idea of decentralization. This was certainly not true - even by the time of Richelieu and Louis XIV - but it was one of Maurras's favorite arguments for a restoration.

Maurras and his associates could not achieve their aims by parliamentary means; they knew that they could only do so by force. " "The crowd", Maurras wrote, "always follows. It follows energetic minorities, and these minorities make history."2 He also said: "In the matter of method, doctrine, and the means as well as the end, the country, in its heart, is completely in accord with us."3 The first of these statements is entirely in agreement with Maurras's temperament and his conception of the tole of the elite. The second statement is a typical piece of Maurrassian hedging. There was no basis for claiming that even a sizable minority of the country was remotely sympathetic to the doctrines of the Action Française, much less "completely in accord" with its methods as well as its doctrine. The phrase "in its heart" constitutes the hedging. It implies that if people knew what was good for them they would support the Action Française.

The program of this movement was "to constitute a royalist state of mind and to prepare the coup de force for establishing the monarchy." In practice Maurras resembled Maurice Barrès in his hope of winning a section of the army to his cause - "We cannot help but succeed with the generals." $\mathrm{He}$ maintained that he wanted a conservative revolution unified by an idea that was true, ${ }^{6}$ and that his proposed military coup was to differ from what he called "the mere pronunciamientos of Spanish and South American generals." Once the propaganda of the Action Française had convinced enough highranking officers to march, that organization, along with the other reactionary groups in the country, would seize control of the government. Existing antimasonic and antisemitic forces would have the task of arresting those persons whom Maurras considered subversive. Meanwhile the Action Française would concentrate its efforts exclusively on gaining control of the ministry of the interior, especially the communications centers. ${ }^{8}$

1 Enquête, p. 418.

Ibid., p. 415 .

Ibid., p. 419.

- Si le coup de force est possible, p. 567; this work appeared as a pamphlet in I909 and was incorporated into the enlarged edition of the Enquête cited in footnote 3, p. 2.

Ibid., p. 576.

Enquête, pp. 420-423.

7 Si le coup de force est possible, p. 548.

${ }^{8}$ Ibid., pp. 569-570. 
It is in his descriptions and analyses of different ways to overthrow the government that Maurras most clearly shows that he is somewhere between the traditional plotter of palace revolutions and the modern conspirator trying to set up a totalitarian dictatorship. That is to say, he is between the two types in temperament. The means he proposes and the consequences he contemplates are amazingly close to those of Lenin, Mussolini, and especially Franco.

Maurras always insisted that the fact that the Action Française had a doctrine made it different from other groups that were trying to overthrow the existing regime. These others failed, he maintained, because they had no fixed set of principles. ${ }^{1}$ He reviewed the case of Boulanger in 1889 , and the events of October 29, 1898 , when General Chanoine, the minister of war, declared that Dreyfus was guilty and resigned from the chamber of deputies while an angry crowd was rioting outside. Maurras also analyzed the failure of Déroulède and his followers to persuade a royalist general to march on the presidential palace on February I 8, I 899. The February riots in 1934 failed too, according to Maurras, because the leagues that tried to destroy parliamentary institutions at that time had no consistent philosophy.

Neither Bonapartism nor fascism appealed to Maurras. He was wary of the man who, "for the moment or the second, was the master of some fraction of the public force on those days of ebullition when there is electricity in the air."2 Not only did such a person lack any legitimate claim to power, but he and his followers could easily be bought by powerful financial groups, as was the case with Pierre Taittinger's Jeunesses Patriotes and François Coty's Solidarité Française in the 1920's and 1930's. Maurras said: "The elected dictator is the servant of the plutocracy, like Theodore Roosevelt, or the servant of public opinion, like Napoleon III. Our dictator must be the servant only of France, and such a man can only be the king." 3 This point of view, which was at first directed against the ideas of Paul Déroulède, and later against the French fascists, clearly distinguishes Maurras from fascist theorists. What he and his disciples wanted was a dictatorking, a man who would resemble a modern dictator in his powers - as opposed to a constitutional monarch - but who, because of his traditional and legitimate claim to authority, would be independent of the plutocracy and the mob.

Maurras's formula for a sound social and economic organization was: peace among the classes, hierarchy, and corporatism. ${ }^{4}$ He blamed the

1 Ibid., p. 559.

2 Ibid., p. 546.

${ }^{3}$ Action Française, April 7, 1908.

4 Gazette de France, July 10, I 902. 
Revolution for having perverted the natural functioning of French society by rejecting these principles. In replacing the authority of the king with popular elections and in trying to enforce legal equality, the democrats opened the door for economic class conflicts. It was because Maurras saw "the false political doctrine of democracy" at the root of contemporary social unrest, ${ }^{1}$ that he emphasized political change as the only way to restore the harmony of French society.

This harmony had to be based on a hierarchical social structure in which everyone had certain duties and differentiated rights. The central government was to have no authority over the citizens without giving them an equivalent amount of local freedom. On the other hand, there was to be no liberty without a corresponding amount of responsibility. ${ }^{2}$ The nobility was to be reconstituted, but it was to be open to all men with creative ability. ${ }^{3}$ It would have a place for commoners like Maurras, so that once the monarchy was restored, those intellectuals who were now working for the public good "in vain" would operate more effectively. They would serve the prince by guiding his thought and by enlightening the masses. ${ }^{4}$

This Maurrassian conception of the new nobility combined the old noblesse de l'épée (feudal nobility), the noblesse de la robe (hereditary magistrates of the king), and the noblesse de la plume (the intellectuals). Maurras had an obvious predilection for the latter. Indeed, there was a superficial resemblance between the kind of society he desired and imperial China - where the ruling class had also been composed of intellectuals - or ancient Babylon, Egypt, India, and Persia - where the priesthood, the "bearers of intellectualism", as Max Weber called them, had a strong influence on the rulers of those countries. According to Karl Wittfogel, the "bearers of intellectualism" in most oriental despotisms were part of a state apparatus that Maurras would have considered too "monolithic". He wanted bis educated elite to be an independent force. Like many modern intellectuals, he believed that their function was to criticize the community in which they lived. But, when no one listened to them, they were tempted to dream of becoming the mandarin class or high priesthood in a utopia of their own making.

Maurras also wanted to rehabilitate the peasant and working classes by making them property owners. He recognized the merits of the captains of industry who, since the end of the eighteenth century,

1 Enquête, p. 417.

Ibid., p. Ioo.

3 Ibid., p. 98.

4 Ibid., p. 208. 
had created new riches. His main complaint against these bourgeois "dynasties" was that they had neglected the welfare of the working class $^{1}$ and had tried to monopolize all the wealth and political power. Maurras felt that the workers' demands for social justice were often "very human"2 and essential for the preservation of the French race. He rejected Marxist proposals for satisfying these demands, because Marxism was an internationalist ideology, while he believed that the nation state was the natural political unit in the modern world. Instead of encouraging class warfare he strove to integrate the French workers into the national economic and social structure by giving them some kind of property - i.e., by "de-proletarizing" them. ${ }^{3}$

According to Maurras, "there is no reason why the laws of peace among the classes should inspire less enthusiasm than the idea of their conflicts." 4 He repeatedly blamed the Third Republic for the poverty of the French working class and said that "there is no relationship between the republican form [of government] and the liberation of the proletariat."5 The monarchy alone can free the workers, because it will destroy one of the evils of the republic, namely, the exploitation of this group of Frenchmen by the class of politicians.

Maurras objected particularly to what he called the manipulation of the workers by the Socialists. For he maintained that the appearance of Socialism in France at the turn of the twentieth century was "a political scandal, nothing more!"B The growth of Socialist parties may have been understandable in Germany, England, and Belgium but not in France, which was less industrialized than these countries. Socialist politicians were foreign to her labor movement, and the workers had a right not to be agitated and exploited by them. ${ }^{\text {? }}$

Despite their professed concern for the industrial workers, Maurras and his followers favored an agrarian economy, and their first consideration was for rural interests. Maurras tried to relate the two by saying that labor conditions could not be improved unless the lot of the peasants was ameliorated first. This was true, he insisted, because it was poverty in the rural areas that drove people to seek

1 Action Française, January 8, 19 10.

2 Ibid., January $28,1927$.

3 Ibid., January 8, igro.

4 Ibid., March 3, 1920.

5 Ibid., December 16, 1912.

Enquête, p. 517.

7 Ibid., p. 57. Maurras's view was shared in part by the conservative republican Daniel Halévy, who said that "socialist enthusiasm is of French origin. But the institution of [Socialist] parties is German and Belgian" (Essais sur le mouvement ouvrier en France [Paris: Société Nouvelle de Librairie et d'Édition, 1901], p. 253). 
employment in urban industries, and these new competitors aggravated the existing hardships of the city workers. If this exodus from the countryside could be stopped, competition among the workers would cease. ${ }^{1}$

Actually rural people were not deserting the French countryside for the reasons Maurras assumed. Those who left were mainly the sons and daughters of marginal farmers and artisans. They were not so much "pushed" by lack of economic opportunities at home (they would have stayed there had there been no place else to go) as they were "pulled" by the prospect of jobs elsewhere. There has been a shortage of labor in the dynamic sections of the French economy throughout most of the twentieth century, while there have been too many Frenchmen engaged in agricultural pursuits, given the national market for their products. Far from neglecting the small farmers, the republican governments helped them to stay in business - albeit at a near subsistence level in many cases - by not making them pay their direct taxes and by putting up high tariffs against foreign competitors.

But Maurras's explanation of the "poverty" in rural France was that the peasants were being dispossessed by tax-collectors and money-lenders. ${ }^{2}$ He said that they had enjoyed full ownership of their land after their ancient communal rights had disappeared, but that they now faced the novel situation of owning nothing, either personally, or in common. Here we see how Maurras shared the reactionary prejudice against mobile wealth. He charged that the over-centralized state mulcted the farmer with its heavy tax levies, while the possessors of "anonymous and vagabond wealth" - who were mostly Jews - took what he had left in interest on loans and mortgages. The fact that the victim sometimes abandoned his farm altogether was bad for the defense of the fatherland - since the peasants were the backbone of the army - and it hurt the nation's productive capacity.

Reactionaries like Maurras spent much of their time attacking the democratic regime for causing the depressed condition of the masses, but they were really opposed to industrial society itself. Maurras himself recognized the fact that industrialization was the main cause of modern class strife when he spoke of this problem in imperial Germany during the late nineteenth century. As a matter of fact, he often pointed to Bismarck's labor laws as an example of how the social question could be solved under a monarchy. Actually, the Bismarckian solution did not end social unrest in Germany, and Maurras had to look elsewhere in his search for the means of re-

1 Ibid., p. 56.

${ }^{2}$ Action Française, July 8, 1908. 
establishing class harmony in France. He found this in the Middle Ages. In that period the peasants, who were socially conservative, were the largest group in the country. If this situation could be restored, along with the monarchy, it would have a stabilizing effect on industrial relations and allow their organization along corporatist lines.

Corporatism occupied only a small place in Maurras's social philosophy. Patrice de la Tour du Pin Chambly de la Charce was its main French spokesman in the early twentieth century, but he was an active member of the Action Française for only a short time. Within the movement Firmin Baconnier expanded Maurras's ideas on this subject. Maurras himself favored the corporation (gild) not only because of the economic prosperity it gave to its members, but also because it integrated them socially. ${ }^{1}$ Baconnier added that the craftsman in his gild was a part of a larger economic community, the town, and that he had to serve its needs as well as his own. Indeed, he continued, "the rights of professional artisans are subordinate to the fulfilment of social and national duties."2

In modern times the organization that most closely resembled the medieval gild was the syndicat - a continental version of the tradeunion. The Syndicalists, like the Action Française theorists, wanted to reorganize France along occupational - or functional - lines, though, like the Socialists, they believed that there was an inevitable conflict of interests between the capitalist and working classes. Despite his abhorrence of class warfare, Maurras saw in syndicalism the germ of a corporative society. ${ }^{3}$ Ultimately, according to him, the syndicats would have to include both employers and workers. He himself sought to achieve his goal of social harmony through the restoration of a class hierarchy - in which there was a horizontal solidarity - but he also believed that there was a kind of vertical solidarity between workers and employers in the same industry. ${ }^{4}$

With an apparent blindness to the impersonal, bureaucratic structure and functioning of a modern industrial firm Maurras asserted that all men connected with the manufacture of a specific product were united by a common bond, ${ }^{5}$ and that this functional tie should be expressed structurally. Like the medieval craft gilds, the corporations advocated by the Action Française would provide retirement pensions,

\footnotetext{
1 Ibid., June 7, r 920. “

2 Le salut par la corporation (Paris: Les Oeuvres Françaises, 1935), p. Io.

3 Mes idées politiques, p. 245.

4 Ibid., p. 22 r.

5 Action Française, September 6, 1908.
} 
social services, recreaction, and on-the-job training for their members. ${ }^{1}$ The employers, in turn, would take an interest in their workers' welfare.

Thus, Maurras believed that the corporation would eliminate class conflict. Both the workers and the employers would identify their interests with the "company", which, according to corporatist theorists, is a kind of family. This notion has recently appeared in the public relations bulletins of some giant American industries - e.g., the "Bell Telephone family". But it is difficult to see the comparison between an assembly-line worker and a medieval cobbler, or between a contemporary business executive (Maurras would have called today's "Organization man" a lackey of "Finance") and the proprietor of a fourteenth-century shop. When Mussolini tried to introduce corporatist forms into the Italian economy, the net result was more state control. Maurras wanted to avoid this as much as the chaos created by economic individualism. ${ }^{2}$ He thought he had escaped both evils by accepting corporatism, but he had less to say about economics than about most other subjects.

In order to be complete, Maurras believed that his monarchical, stratified, corporatist utopia needed one more element - the Roman Catholic Church. He did not subscribe to the principles of Christianity, and some of his colleagues were also either avowed atheists or Catholics in name only. Still, he respected the church because he believed that it had preserved many pagan traditions in its ritual and arrested the development of the anarchy implied in the Gospel by the strong social consciousness it had inherited from the Roman Empire. For him it was an external and visible authority, the embodiment of discipline, hierarchy, and order. ${ }^{3}$

These were the values that Maurras cherished, but they were not based on divine sanction. Although statements can be found in his writings that seem to indicate a concern for the need to curb human vices like selfishness, avarice, cupidity, and hatred, Maurras, like Comte - until his later years, when Comte developed a curious pseudo-religion of his own - felt that society, not God, was the authority regarding morality. In this respect Maurras differed from the traditional reactionary writers. The leader of the Action Française was a positivist - he was concerned with the natural, rather than the

1 Revue de l'Action Française, IV (June 1901), Pp. 97-99.

${ }^{2}$ He agreed with La Tour du Pin, who said: "Le régime corporatif est la seule manière de ne pas aller du libéralisme au socialisme" (Aphorismes de politique sociale [Paris: Nouvelle Librairie Nationale, 1909], p. 20).

${ }^{3}$ La démocratie religieuse, p. 177 . 
supernatural, order in the world. He openly acknowledged his debt to Comte for helping him to develop his method of social analysis, which he called "organizing empiricism".1

A moral philosophy without a religious foundation could have little appeal for practicing Catholics, and pious supporters of the Action Française prayed constantly for Maurras's conversion. But he stubbornly refused to compromise his atheism throughout his life, even when such a gesture might have saved his movement from the papal ban in 1926. His theory of society had no logical place for a supernatural God or for "sentimental" preaching. Maurras hated Christianity almost as much as Nietzsche did. He once told a Catholic colleague: "With your religion you have dirtied the world in a most bizarre way for eighteen hundred years."2

Maurras was a clerical only because he was an authoritarian and a traditionalist. During the Vichy period he approved of Pétain's efforts to revive the family unit with the aid of the church. He also liked the emphasis on discipline and obedience to authority instilled in French boys and girls by the Catholic teaching orders. Finally, he shared the feeling, once expressed to him by Jules Lemaitre, that the church was a part of France's cultural heritage: ${ }^{3}$

"Even when our religion will be no more than a memory, a sort of inherited emotional disposition, it will be as Catholics as much as Frenchmen that we shall feel ourselves different - without rancor, moreover - from Englishmen and North Germans."

In reality, however, Lemaitre, Maurras, and the other intellectuals in the Action Française were more interested in political action than in religion. Throughout his life-long campaign for his ideal society Maurras subordinated religious, economic, and social questions to politics. He claimed that his doctrine of integral nationalism encompassed all the problems of France:

"That is why, without rejecting any eventual alliance, in adhering in advance to all those unions that are or that will be useful to the triple defense of religion, society, and the fatherland, in accepting them and in desiring them all, we hold to this program - politics first [politique d'abord] nationalist politics - the politics of integral nationalism."4

1 Trois idées politiques, in: Romantisme et Révolution (Paris: Nouvelle Librairie Nationale, I925), pp. $261-262$.

${ }^{2}$ Louis Dimier, Vingt ans de l'Action Française (Paris, Nouvelle Librairie Nationale, 1926), pp. 29-30.

3 Enquête, p. 366.

4 La politique religieuse, pp. $375-376$. 
Maurras's ideas regarding the church were therefore more closely related to the means of making his political philosophy prevail than to its basic values and goals.

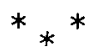

Charles Maurras tried to construct a synthesis of counterrevolutionary doctrines in the form of a barrage of solid arguments and subtle ideas. His social thought expressed a set of reactionary attitudes that would not die in France. These were not only antidemocratic and antiegalitarian but also anti-etatist. Maurras was the champion of those Frenchmen who felt insecure in a modern, impersonal, political and economic structure. His program of federalism - or decentralization reflected a desire to restore the hierarchical society of the medieval manor and town. He wanted to replace the agents of the central power - which, of course, had been developed by the monarchy beginning in the twelfth century - with municipal councils and regional assemblies in which the local aristocracies would be the controlling authorities. ${ }^{1}$ Interpersonal relations would thereby be restored to France's political system.

Such a restoration would only work within the framework of stratification, privilege, and hereditary power. According to Maurras, these features, along with the inviolability of property - especially family property - are essential for an ordered and satisfying social life in France. ${ }^{2}$ His conception of the union of property and power is feudal. It leads logically to a caste system in spite of the fact that he wanted to keep his privileged classes open to a few men of talent. (After all, even in the Middle Ages, such people could "rise" in the church.)

Maurras believed that only a society founded on the principles of authority, order, and hierarchy could avoid the ravages of class conflict and civil war. Civilization itself, according to him, was threatened by these evils, which are the inevitable consequences of the French Revolution. But again, one asks, what kind of civilization did Maurras prize most highly? If it was that of ancient Greece, he would have to look to Sparta - a Sparta favorable to the arts, though - for Athens in its heyday was a democracy. The Roman Republic at the time of Cicero also appealed to him, but it was a mere interlude of patrician ascendancy between the social strife under the Gracchi and the despotism of the Caesars. One must conclude, then, that, despite

1 Action Française, November 24, 1922.

Ibid., April 4, 1916. 
his reverence for classical culture and the regime of Louis XIV, Maurras championed an idealized version of the Middle Ages.

He wanted to restore a society of small producers who took pride in their craftsmanship and respected the sanctity of the family, of petty noblemen who played a paternal role toward the toiling masses, and of local governments that reflected a diversity of interests. Aside from his professed positivism and his advocacy of extremist tactics, Maurras clung to the values of the prerevolutionary tradition. The Action Française ideology, shorn of its invective and its casuistry, expresses a nostalgia for a hypothetical golden age. It is not of this world. In twentieth-century France other political movements have found more earthy and practical slogans with which to attract those "victims" of democracy and industrialization who want to turn back the clock. 